\title{
Ion Trap
}

National Cancer Institute

\section{Source}

National Cancer Institute. Ion Trap. NCI Thesaurus. Code C70839.

A device used to prevent ions in an electron beam from striking other apparatus. 